\title{
A Study of the Narrative Discourse in Balinese Malay Language to Increase the Culture of Literation
}

\author{
I Nyoman Suparwa, Made Sri Satyawati \\ Indonesian Literature, Faculty of Arts \\ Udayana Unversity \\ Bali, Indonesia \\ suparwa_nym@yahoo.co.id
}

\begin{abstract}
The purpose of this study was to find the discourse system. By using observation methods, the data collected in the form of oral and written data by informants in the village of Loloan, Jembrana, Bali. The data obtained were processed through speech analyzer and analyzed based on discourse theory. This research was very important to be implemented because it can provide theoretical linguistic benefits in the field of discourse. The discourse studies will apply various concepts in the field of discourse, both variant and universal. The application of various concepts (theories) is seen in the discovery of unique characteristics of Balinese Malay language. These various findings are certainly very useful because they are a contribution to the treasures of Indonesian discourse theory and linguistics in general. For applied linguistics, this research is useful especially in terms of the application of discourse patterns in language teaching, both Malay and Indonesian. With the recognition of the Balinese Malay language discourse formation pattern, the teachers of Malay and Indonesian languages can develop discourse formation methods and discourse analysis, both in the form of lecture modules and in the form of textbooks. It is also related to the tradition of sharing partners, both oral and written. Thus, this study can improve the culture of literacy (read-write) in the Balinese Malay community.
\end{abstract}

Keywords: narrative discourse, Balinese Malay, literacy culture

\section{INTRODUCTION}

The narrative discourse of the Balinese Malay language refers to the oral story (Folklore) told by the Loloan community, a minority Muslim group in Jembrana Regency, Bali. In general, the language is only used orally; do not have a written tradition or a writing system. The language is used by local people in daily life, such as in family, religion, education and local transactions (Suparwa, 2007). In the Loloan Community, especially the younger generation, the preservation movement and the development of cultural traditions, including language, continue to be encouraged. The Loloan youth association which called itself the Loloan Youth Community initiated the $30 \mathrm{M}$ movement at the Reading House (Bali Post, 2018: 10). The movement is in the form of reading activities for 30 minutes every day. It was done to improve the literacy culture of the Loloan community because it was suspected that the reading of the young generation had recently been eroded by the swift influence of playing gadgets, gossiping people, or the like. With literacy, they can find information and knowledge that can be accounted for. In addition, the material that has been read can be discussed directly with friends in the community scientifically. At this time the Reading House has collected about 800 books since it opened in 2016. For that reason, the study of Balinese Malay language, especially the field of discourse, can contribute to the results of the study in literacy activities.

This research will focus primarily on four things to express the issue of discourse in the Balinese Malay language, which are:

(1) What is the structure of the narrative discourse of the Balinese Malay language?

(2) How is the cohesion of the narrative discourse of Balinese Malay language?

(3) What is the language function in the narrative discourse of Balinese Malay?

(4) What is the context of the narrative discourse situation of Balinese Malay?

The discourse study concerning the microstructure and macrostructure in the narrative discourse of Balinese Malay language can be used as a reference in advanced studies of discourse such as critical discourse or political discourse. These studies 
can enrich knowledge about the language, literature, and culture of Balinese Malay which certainly can excite the culture of literacy in the Balinese Malay language community itself. This research is a followup of the previous study of Balinese Malay language. In a previous study, the study of Balinese Malay language in the form of sound studies (phonology), words and sentences (morpho-syntax), dictionaries, and the study of sound-symbol writing problems and applied to criteria writing in Malay. In this proposed research proposal, the research problem and the range of problems are focused on discourse (text) which is an oral speech that uses a broader and more complete Malay language.

\section{RESEARCH METHOD}

This research was conducted by applying a qualitative approach that focuses on the nature of observation, the depth of text data, process-oriented and discovery, inductive, descriptive, explanatory, and dynamic reality (bd. Nunan in Finch, 1992: 4). Operational steps in data collection will be carried out with observation and interview methods supported by recording techniques and recording techniques. In general, there are three types of data collected: (a) audio-visual material, (b) written documents/texts, and (3) information. The first two data types are obtained by the observation method, while the last one is collected through the interview method. Meanwhile, in data analysis and interpretation, the operational steps are: (a) data understanding, (b) data processing, (c) preparation for analysis, (d) initial analysis, (e) in-depth analysis, and (f) editing (cf. Cresswell 2009: 177-195)

The data source of this study is narrative discourse in the form of Malay-language tales (Loloan) Bali. The tale generally tells the story of animals with their respective titles (1) Sang Darek ajak Sang Kue, (2) Empat Ekor Sampi (3) Pesen Mak, (4) Alkisah (Cerita Nenek Rate), (5) Kancil Nyuri Ketemun, (6) Kerbo yang Belog, (7) Tekos ajak Singe, dan (8) Kancil jak Bekecot. The story was examined with a data collection method is a method of seeing to find a discourse cohesiveness system; then, the method of analysis is descriptive explanatory, which is in the form of descriptions with words and accompanied by an explanation.

\section{RESULTS AND DISCUSSIONS}

Narrative discourse/text is generally formed from clauses that relate and relate one's experience. De Fina and Johnstone in Tannen (2015) explained that the clauses that make up the narrative text function as referential and evaluative. Referential is related to clauses used in the form of stories about events, characters, and settings. Meanwhile, evaluative is a clause that relates to the reason the narrator tells the story and the reason the listener or reader needs to listen to it.

To create a discourse/text composed of a series of clauses or sentences and framed so that the text is systematic and directed, the text must have structure, cohesion, function, development, and character. All the peculiarities of the text cannot be separated because the text has property unity (Halliday, 2005: 222). For this reason, the narrative discourse in this study is discussed in four sub-topics, namely (1) the structure of the text, (2) cohesion, (3) the language metaphysics, and (4) the context of the situation.

\section{a. The Structure of the Text}

In general, text that is classified as the narrative has its own framework/structure that distinguishes it from other types of text. The structure of the narrative text consists of five things, namely (1) orientation, (2) complications, (3) climax, (4) resolution, and (5) orientation. In the story of "Sang Darek ajak Sang Kue," there were several stages of text structure found as follow.

\section{b. Orientation}

In this stage, Sang Darek and Sang Kue met on the riverbank, with the choice of the word kadongan ade banjir "while there is a flood '. They planned to plant banana trees each one tree. It was also told the nature of Sang Darek (monkey) who was good at seducing Sang Kue (turtle) which was certainly more innocent, so Sang Kue wanted to grow banana trees together.

\section{c. Compilation}

In this stage, the banana trees had begun to grow large In this connection, Sang Darek always checked by pretending to ask questions and comparing the trees he planted with the banana tree of Sang Kue, so that Sang Kue would not be suspicious that Sang Darek had a bad intention.

\section{d. Climax stage}

At this stage, it was told that the banana of Sang Darek was ripe, but he said, it hadn't yet, so Sang Kue did not come to see him because he could pick the banana for himself. In the climax, it was said that not a single banana is given to Sang Kue who waited under a tree. To the extent that the banana skin was not given.

At the end of this stage, Sang Darek even took a dump into Sang Kue's mouth, when Sang Darek promised to give one comb of banana and Sang Kue was told to open his mouth facing up.

\section{e. Language Cohesion}

In reality, cohesiveness is achieved using cohesion and without cohesion tools. Generally, the discourse found in the narrative of Balinese Malay is a dialogue that does not explicitly use cohesion tools even though all of the discourses are cohesive 
because they are neatly arranged and can be understood by the listeners. In the non-dialogue paragraph, the use of cohesion tools is found, such as the repetition of the singular keyword singe 'lion,' the use of the pronoun die 'he,' the use of teros 'continues' as conjunctions and the use of mixed cohesion tools.

For example, the cohesiveness in the Balinese Malay narrative story can also be found in Sang Darek and Sang Kue story. There, it was shown that the continuity of the story and could be understood well by the interlocutors. In reality, cohesiveness is achieved using cohesion and without cohesion tools. The following example shows the cohesiveness achieved with no cohesion tools.

$\begin{array}{ll}\text { Sang Kue } & \text { : "Sang Darek, mintak le aku” } \\ \text { ('Sang Darek, please give me a bit) } \\ \text { Sang Darek } & \text { : "Manjet le kau!" ('Climb up } \\ \text { Sang Kue } & \text { yourself!') } \\ & \text { aku daku dak bise manjet, mintak le } \\ & \text { please just give me a bit!') }\end{array}$

\section{f. Language Metaphysics}

Balinese Malay stories contain actors who live their lives according to the path determined by the author of the story. Those stories are a reflection of life that can be either good or evil. Everything is a lesson for the younger generation to imitate for good or to avoid the bad. However, everything is a reflection of life. In terms of language usage, all of the stories are presented in Balinese Malay language which is very simple because the use of the language is generally used for children, so that it is adapted to the language patterns/rules of children to be easily understood and digested.

\section{g. Context of Situation}

The context of the situation is strongly related to variations in language and language functions. The context of the situation will produce language variations or vice versa. According to Halliday (2004), the context of the situation relates to three things, which are fields, tenors and modes.

(1) Field refers to what is happening, to the nature of ongoing social action.

(2) The tenor is related to the relationship between communication participants, both verbal and nonverbal; relationships are vertical, horizontalvertical, temporary or permanent.

(3) The mode is the mediation between fields and tenors, in social interaction, the role of language is empowered, so that forms of communication, variations in language, equipment/tools, phonological forms must be considered.

In the Balinese Malay narrative story, the field concerns the questions related to the environment of events such as: when, where, how the incident occurred, why the incident occurred and so on. For example, in the story of Nyarik Ikan (Nyerok), the field refers to the activity being told. The fishing activity was carried out on the beach using nyareng, nyerok, manceng, and melantek (tying, hammering, sharpening, and slamming). The process of the incident occurred described below.

"Kalok lame orang-orang tu nyari ikan make sampan. Pake nangkep ikan make serok. Tapi karangini makek perau mesin, nangkep ikan makek jaring. Hasel tangkepan tu jualnye di pabrek-pabrek, ade gaan jualnye same orangorang yang meli ikan di pengger pante yang namenye melantek. Orang yang melantek nyual ikan yang dibelinye tu di pasar."

\section{CONCLUSION}

(1) The structure of the Balinese Malay narrative discourse consists of (a) the orientation stage, then (b) the compilation stage, then followed by (c) the climax stage, followed by (d) the resolution stage, and ends with (e) the oriented stage. The discourse structure used follows the structure of narrative discourse in general, namely by following the arrangement as mentioned in (a) to (e).

(2) Cohesiveness in the narrative of Balinese Malay is shown by the continuity of the story and can be understood well by the interlocutors.

(3) Language metaphysics in the Balinese Malay language narrative discourse in the form of narrative partnerships have more functions as a tool to interact in terms of conveying advice/lessons/ human values to others, especially the younger generation (children).

(4) The context of the situation is strongly related to variations in language and language functions. The context of the situation produces language variations or vice versa. In the Balinese Malay narrative story, the context of situations was related to the environment of events such as: when, where, how the incident occurred, why the incident occurred and so on.

\section{REFERENCES}

[1] Alwi, Hasan, dkk. 2003. Tata Bahasa Baku Bahasa Indonesia (Edisi Ketiga). Jakarta: Balai Pustaka.

[2] Dixon, R.M.W. dan Alexandra Aikhenvald. 2006. Complementation: a Cross-linguistic Typology. New York; Oxford University Press.

[3] Bali Post. 2018. "Bangkitkan Budaya Literasi Pemuda Loloan Inisiasi Gerakan30MB di Rumah Baca”. Denpasar.

[4] Bradan, Arifin. 1995. Loloan: Sejumlah Potret Ummat Islam di Bali. Jakarta: Yyasan Festival Istiqlal II. 
[5] Brown, Gillian dan Yule, George. 1983. Discourse Analysis. New York: Cambridge University Press.

[6] Dixon, R.M.W. dan Alexandra Aikhenvald. 2006. Serial Verb Constructions: A Crosslinguistic Typology. Oxford, UK: Oxford University Press.

[7] Dixon, R.M.W. 2010. Basic Linguistic Theory. New York: Oxford University Press.

[8] Eggins S. 1994. An Introduction to Systemic Functional Linguistics. Pinter Publishers: London.

[9] Ekowardono, B. Karno. 2002. Kalimat Dasar Bahasa Indonesia: Kajian Tentang Ciri dan Tipenya. Dalam Alwi, Hasan dan Dendy Sugono. Telaah Bahasa dan Sastra. Jakarta: Yayasan Obor Indonesia.

[10] Gussmann, Edmund. 2002. Phonology: Analysis and Theory. Cambridge: University Press.

[11] Halliday, M.A.K. 1975. Language as Social Semiotic. New York: Routledge, Chapman and Hall, Inc.

[12] Halliday, M.A.K. dan Ruqaiya, Hasan. 1985. Language, Context, and Text: Aspect of Language in a Social-semiotic Perspective. Victoria: Deakin University Press.

[13] Hawkins, Peter. 1984. Introducing Phonology. London: Hutchinson.

[14] Holton, G. 2005. The Representation of Oral Literature and its Role in Language Revitalization. The University of Alaska Fairbanks.

[15] Kridalaksana, Harimurti. 1995. "Pendayagunaan Potensi Intern dan Ekstern dalam Pengembangan Bahasa Indonesia dan Peningkatan Budaya Bangsa"; makalah dalam Seminar Nasional Sejarah Bahasa Indonesia dalam Perjalanan Bangsa, 27-28 Juli 1995. Denpasar: FS Unud dan Program Magister (S2) Linguistik Unud.

[16] Kridalaksana, Harimurti. 1996. "Bahasa Daerah dan Kebudayaan Nasional". Dalam Pesamuhan Agung Bahasa Bali IV. Denpasar: Pemprov Bali.

[17] Kroeger, Paul. 2005. Analyzing Grammar: An Introduction. New York: Cambridge University Press.

[18] Laksmi, Anak Agung Rai. 1984. "Kata-kata Pungutan Bahasa Bali dalam Dialek Melayu Bali di Kecamatan Negara” (skripsi). Denpasar: Fakultas sastra Unud.

[19] Sasangka, Sry Satriya Tjatur Wisnu. 2014. Kalimat. Jakarta: Badan Pengembangan dan Pembinaan Bahasa, Kementerian Pendidikan dan Kebudayaan
[20] Sudaryanto. 1993. Metode Linguistik (Bagian Pertama dan Kedua). Yogyakarta: Duta Wacana University Press.

[21] Suparwa, I Nyoman. 2007. "Pola Bunyi Bahasa Melayu Loloan Bali: Kajian Fonologi Leksikal dan Posleksikal". Disertasi Program Doktor Linguistik Unud. Denpasar: PPs Unud

[22] Verhaar, J.W.M. 2012. Asas-Asas Linguistik Umum. Yogyakarta: Gajah Mada University Press 